\title{
La grafía en la historieta: modos, lugares y estéticas.
}

\author{
Octavio Beares
}

Octavio Beares San Martín (Oviedo, 1970) es licenciado en Geografía e Historia por la Universidad de Santiago de Compostela, y diplomado en Restauración y Conservación de Bienes Culturales por la Escuela Superior de Conservación y Restauración de Pontevedra. Comienza a escribir sobre cómics en su blog personal, El Octavio pasajero, y posteriormente en el blog Serie de Viñetas, especializando esta bitácora del site Gente Digital en historieta. Colabora en medios digitales como Culturamas o la revista Viñetas en Palabras. Cofundó en 2012 el blog Quadriños, del diario digital Praza Pública. Ha escrito sobre historieta en medios impresos (puntualmente en Guia Cicerone y Xornal de Galicia, en Rockdelux entre 2011 y 2012) y desde 2009 realiza una sección quincenal sobre cómic en Faro de Vigo, donde también colabora como crítico de música. Participa en el magacín A estación, de Radio Redondela, hablando de tebeos. Ha organizado los Primeiros Encontros coa banda deseñada. O cómic no museo, para el Museo de Pontevedra, en 2012. Codirige CuCo, Cuadernos de cómic. 


\title{
Resumen
}

El presente estudio muestra algunos de los aspectos más significativos de la relación entre la letra y el dibujo en el cómic. Como forma narrativa mixta, con letra y dibujo en su seno, la historieta supone un espacio de interrelación entre formas de expresión humana aparentemente opuestas. Sin embargo, la confluencia de posibles contrarios promueve cruces excitantes.

Lo que a continuación se analiza es el lugar que corresponde a la letra escrita en una narrativa gráfica, los diferentes significados, lugares y formas de plasmar letra, en la página de cómic.

\begin{abstract}
This work presents some of the most significant aspects of the relationship between letter and drawing in tcomics. As a mixed narrative form, with letter and drawing in a shared space, comic art is a place for interrelation of apparently opposite forms of human expression. However, the confluence of potential opponents promotes exciting crosses.
\end{abstract}

This text analyzes the place that corresponds to the written letter in a graphic narrative, the different meanings, places and ways to portray letter in the comic page. 


\section{Introducción}

En la primera parte de este análisis sobre la letra escrita dentro del espacio icónico-narrativo que supone la página de historieta, publicado en el número 1 de la presente revista, ${ }^{1}$ hicimos una panorámica histórica sobre cómo, en sus primeros años de formación y hasta la década de los treinta, el papel de la grafía va encontrando su equilibrado lugar dentro del cómic.

Pero es necesario enfrentarse también a la realidad polisémica de esta unión letra-dibujo, que superando las descripciones cronológicas, debe enfocarse desde diferentes perspectivas. Consciente del enorme campo de estudio que supone esta compenetración entre la escritura y el dibujo, no pretendo ser exhaustivo pero sí señalar diferentes vías de aproximación a la naturaleza de la escritura en el noveno arte. Analizaré a continuación algunos aspectos que atañen a la grafía en los cómics a lo largo de tres capítulos: modos de reproducción de la letra escrita en la historieta, ubicación del elemento textual en la narración comicográfica y una aproximación a la letra como elemento estético y visual. Queda al margen un colofón al presente trabajo, que estudie las propiedades narrativas de la grafía en el lenguaje historietístico, aspecto que no considero menor pero que se reserva, de momento, para el futuro.

\section{Modos de reproducción de la letra en la historieta.}

Al acto de escribir los textos en las páginas del cómic se lo denomina rotular ${ }^{2}$ y el proceso se ha ligado de un modo tan claro al arte del historietista que incluso existe un profesional específico del trabajo consistente en completar las páginas dibujadas añadiéndole los mensajes escritos: el rotulista. De hecho en una industria tan compartimentada como la del comic-book norteamericano no es extraño que la tarea de escribir los textos en las planchas corra, efectivamente, a cargo de un tercero que no es el dibujante ni el entintador. ${ }^{3}$

A la hora de que un dibujante de cómics o su rotulista plasmen escritura en su obra, la vía más directa, evidentemente, es la de que él mismo la ejecute. Hablamos entonces de escritura manuscrita o rotulación manual, pudiendo ser esta realizada directamente en el original o en un medio aparte (por ejemplo sobre un pliego de acetato transparente que se superpone al dibujo original, o realizando un collage). La letra manuscrita es la solución más habitual aunque no la única, y cabe defender unas características que resaltan su idoneidad. Al tratarse de un trabajo manual, este tipo de rotulación no obedece a imperativos tecnológicos de ningún tipo más allá de los útiles de escritura, y adaptará cualquier característica gráfica que se le quiera atribuir a la grafía, a la directa voluntad del escribiente.

La rotulación manual ajusta las características visuales de un texto escrito (caligrafía, tamaño, color de la fuente, ubicación espacial de los elementos escritos dentro de la pá-

\footnotetext{
${ }^{1}$ Beares, O. "La grafía en la historieta: evolución de la combinación de texto y dibujo en los orígenes y primer desarrollo del cómic", en CuCo, Cuadernos de cómic n. 1 (septiembre de 2013), pp. 63-90, disponible on line en http://cuadernosdecomic.com/descargables/cuadernosdecomic 1.pdf

2 En palabras de Luis Gasca y Román Gubern, la rotulación es "El tratamiento gráfico del texto literario". Gasca, L.y Gubern, R. El discurso del comic. Madrid, Ediciones Cátedra, 1994, p.480.

3 Un comic-book, sobre todo en el caso de las editoriales más comerciales como Marvel o DC, es el resultado, antes que de una voz autoral, de un equipo donde suelen caber guionista, dibujante a lápiz, entintador y también rotulista.
} 
gina y la viñeta, etc.) a las características del dibujo, y también a la forma y cualidades del contenedor. Para ilustrar esta idea pensemos en globos y cartuchos de texto, evocando ejemplos como Krazy Kat con su grafía "nerviosa" perfectamente adaptada al marco que suponen los bocadillos de George Herriman (FIG. 1). Es evidente que la escritura manuscrita permite un control total y artesanal del producto definitivo, al menos en lo que respecta a las características del rotulado de la obra.

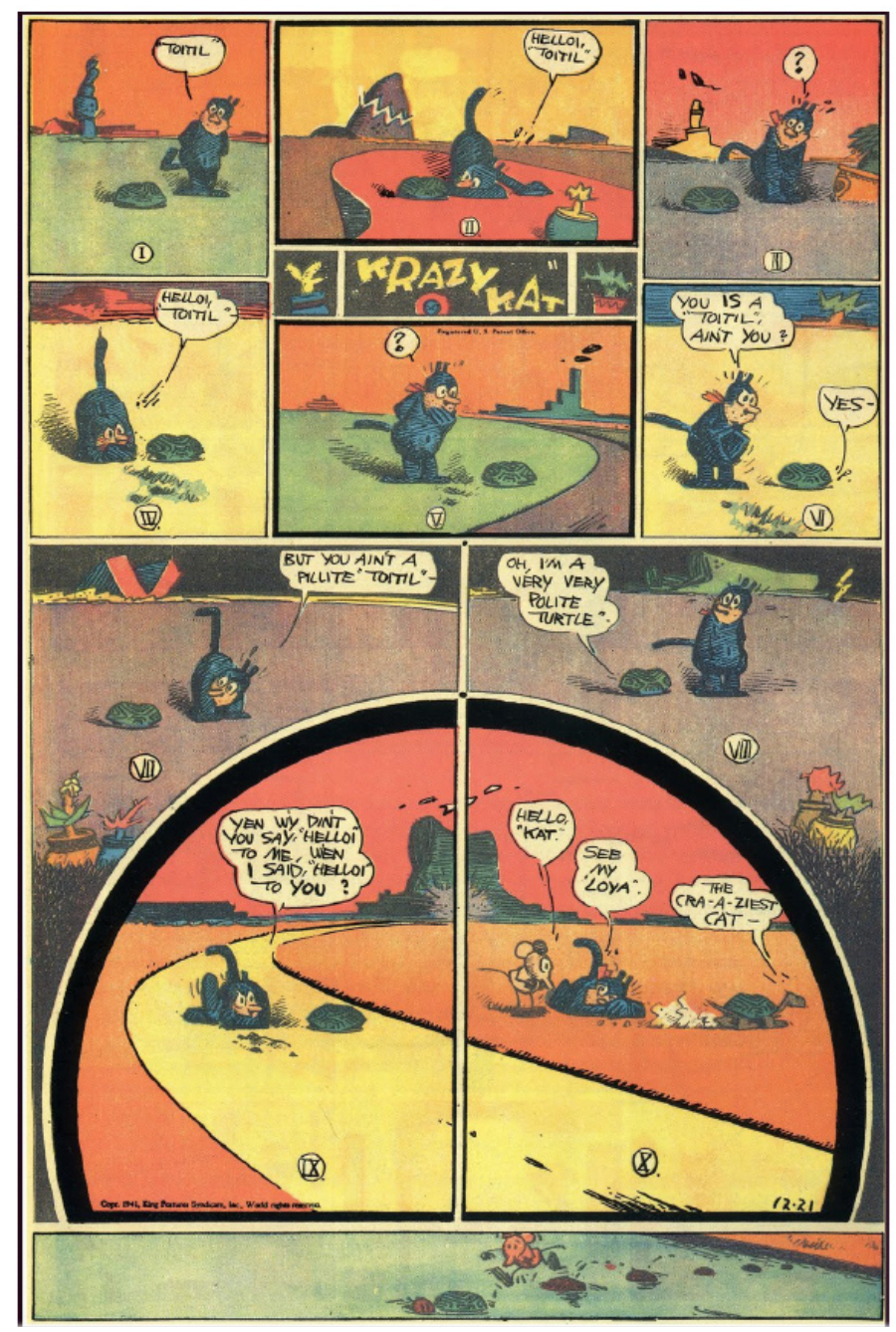

FIG. 1. Krazy Kat. George Herriman, 21 de diciembre de1941.

Sin embargo la historia nos ha demostrado que no es la rotulación manual la única empleada. Incluso dentro de las maneras de escritura "a mano", podemos encontrar fórmulas mecanizadas que alejan el acabado artesanal del producto final, caso del empleo de plantillas de rotulación. Y en este camino que aleja la letra escrita de la impronta personal y la acerca a modos mecánicos, destaca la rotulación mecánica de imprenta. De su uso podemos derivar varias consideraciones. La utilización de medios mecánicos para completar la obra final se da ya en los inicios de la historia del cómic con numerosos ejemplos donde las didascalias acuden a letra de imprenta. Se aporta el mensaje escrito en un paso posterior al de la ejecución del dibujo y cedida la responsabilidad del resultado final a procesos industriales.

Podríamos acudir a no pocos ejemplos, aunque a modo ilustrativo ofrecemos la FIG. 2, de uno de los autores pioneros de los tebeos españoles. Eduardo Sáenz Hermúa (1859- 
1898), quien firmó sus historietas con el apodo "Mecáchis", participa de no pocas características ya aludidas a otros pioneros en la primera parte de este estudio, ${ }^{4}$ y nos sirve también para ilustrar el empleo de rotulación mecánica.

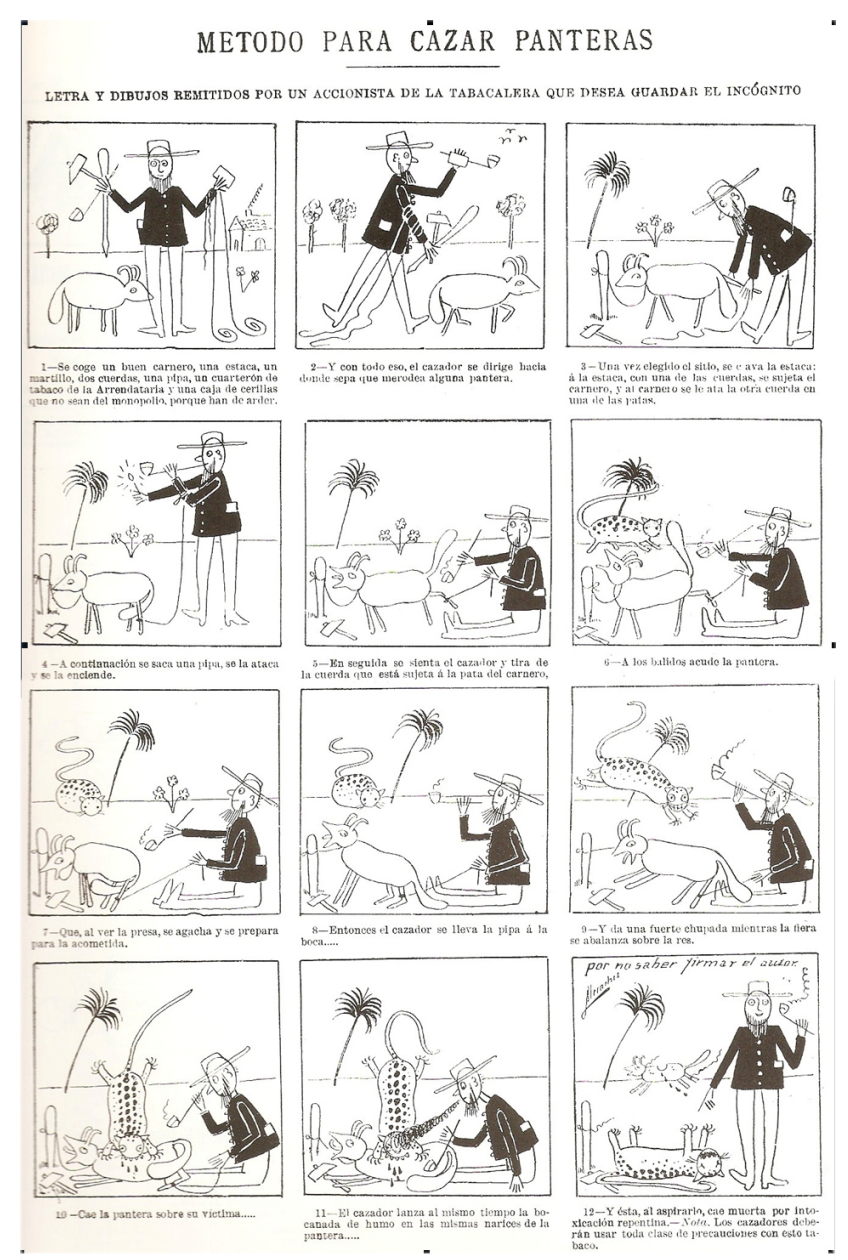

FIG 2. "Método para cazar panteras", Blanco y Negro n. 186. Mecáchis, 1894.

La claridad y legibilidad eran claves tenidas en cuenta a la hora de emplear textos didascálicos en los primeros albores del cómic, y sin duda la opción de utilizar la neutra grafía de las imprentas era una posibilidad de éxito en esta meta. Mecáchis es plenamente legible incluso cuando más de cien años nos separan de esta plancha, aunque la tipografía mecánica quizás no pueda aportar muchos más valores estéticos, dramáticos o de cualquier orden (existen notables excepciones, como se verá en el último capítulo de este estudio). Pero en todo caso, lo que es evidente es que en los tebeos del siglo XIX, embrionarios en no pocos aspectos, la decisión de emplear la rotulación de imprenta se entiende como opción no tanto voluntaria y autoral sino como pragmática y utilitaria.

No ocurre lo mismo si analizamos la azarosa historia de la historieta española. Pese a haber constituido uno de los mayores referentes de la cultura popular con la recuperación

\section{${ }^{4}$ Ibid.}


económica tras la contienda civil y hasta bien entrados los años setenta, ${ }^{5}$ con personajes y cabeceras de fama generalizada como pueden ser el Capitán Trueno o la revista TBO, hasta hace relativamente poco el cómic no fue socialmente considerado en su vertiente artística, sino como producto fungible, y para un supuestamente vano entretenimiento infantil. Este hecho tiene no pocas consecuencias y propició un paisaje artístico e industrial muy característico de la historieta española. Un aspecto que nos interesa ahora del mismo es, precisamente, el abuso de las editoriales con obras y autores, en aras de abaratar y economizar el rendimiento del producto. Solo desde esta óptica se puede entender que títulos longevos en el tiempo hayan combinado rotulaciones manuales y mecánicas. E1 hecho de que muchas veces la labor de rotulación sea de imprenta como en el caso de la FIG. 3, en vez de recaer dicha responsabilidad sobre el autor o autores (rotulación manual), evidencia una prioridad no artística, sino editorial. Un factor decisorio para tomar partido por una rotulación de imprenta podría ser, en este sentido, que la editorial pretende reducir gastos en relación a los costes, o ser eficaces en los ritmos de publicación (por ejemplo, en publicaciones semanales, donde el trabajo en cadena, y además mecanizado, ahorra tiempo). Se sacrifica el acabado estético de la obra en beneficio de la puntualidad y la economía en un producto, no lo olvidemos, rentable y mercantilmente próspero. ${ }^{6}$

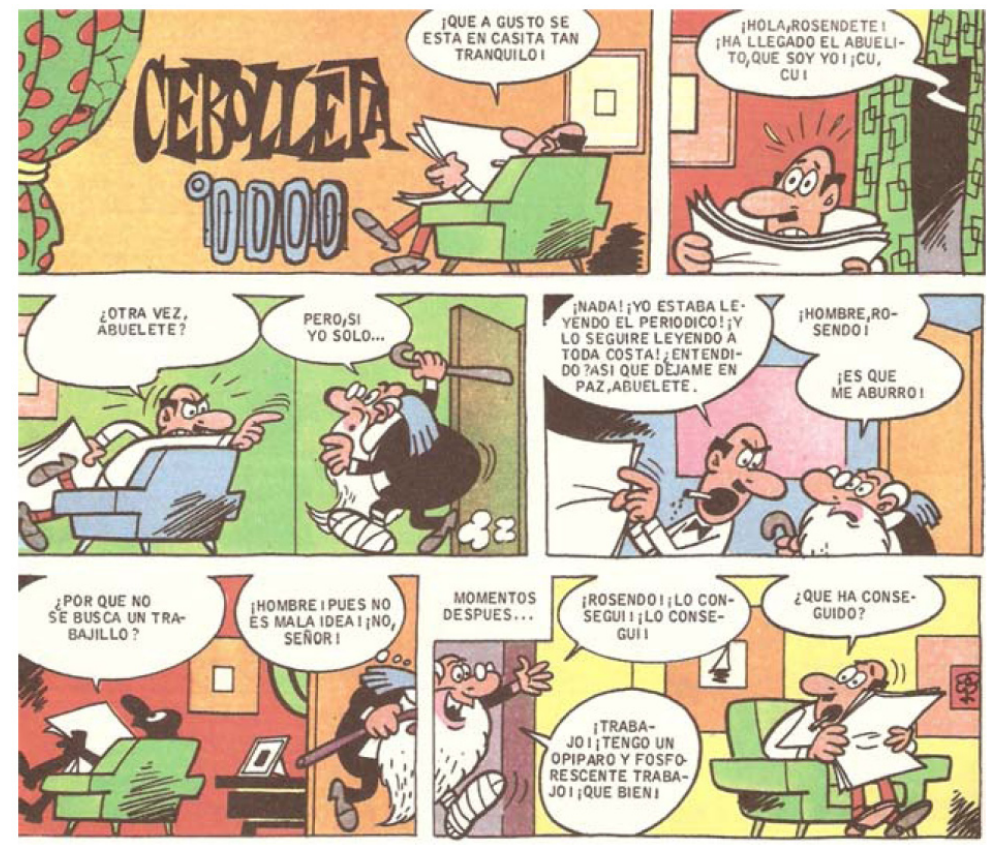

FIG. 3. La Familia Cebolleta, DDT, 3a época, n. 518. Manuel Vázquez, 1977.

\footnotetext{
5 Sobre la popularización del tebeo español en este período comenta Antonio Martín
}

...conforme el tebeo se afianza como lectura fácil, crece otra vez el público, y este proceso, repetido contantemente, aumenta las relaciones preexistentes entre los tebeos, la imagen y la cultura popular, ahora de masas. Hasta niveles de tal intensidad y profundidad, que solo podremos valorar con justeza la importancia que el tebeo ha alcanzado en la sociedad española del siglo xx, cuando conozcamos la correlación entre población total, población infantil, población activa, precios de los tebeos, tiradas y costes generales de subsistencia. (Martín, A. Apuntes para una historia de los tebeos. Barcelona, Ediciones Glénat, 2000, p. 125).

${ }^{6}$ Francisco Ibáñez, entrevistado por Santiago García, define taxativamente a la editorial Bruguera reconociendo que "Había una Escuela Bruguera, porque Bruguera lanzó una forma de hacer las revistas que dio en el clavo, y dio en el clavo porque aquello se vendía, económicamente dio buen resultado." García, S. "Entrevista a Francisco Ibáñez", U, el bijo de Urich, revista de estudio de la bistorieta n. o 8, (enero de 1998), pp. 34-35. 
La página de la FIG. 3 se trata de una plancha de La Familia Cebolleta, de Manuel Vázquez Gallego (1930-1995), y puede servir a la reflexión. El ejemplo propuesto corresponde a una tira de 1977. Este título dio comienzo en la revista DDT en 1951, por lo que tanto la serie (enormemente popular) como su autor, creador también de iconos como Anacleto, Agente Secreto o Las Hermanas Gilda, eran en los setenta verdaderos clásicos en activo. Sin embargo, poco importa si la voluntad de Vázquez era el rotular manualmente o no: la opción mecánica en este ejemplo parece una imposición y lo parece porque en un examen visual de la obra nada nos ofrece, nada expresa esa grafía salvo un acabado frío y carente de armonía en el contexto, tanto de la viñeta como por supuesto del espacio interno del globo de texto. Buen ejemplo de esto último lo vemos en la tercera viñeta, donde un generoso globo contiene un escueto y apretado texto (“¿Otra vez, abuelete?”) dispuesto sin el menor celo por el resultado gráfico de la operación.

De hecho la rotulación mecánica ha sido un severo lastre en la industria de la historieta española en más ocasiones. Hay ejemplos tan poco edificantes como las versiones al castellano de las aventuras de Astérix el Galo, pues la obra creación de René Goscinny (1926-1977) y Albert Uderzo (1927), posiblemente con el Tintín de Hergé el cómic europeo más famoso de la historia, ha recibido el desprecio de no emular en su traducción castellana el acabado original (letra manuscrita, refinada y visualmente bella, un todo con los dibujos suaves y al tiempo vigorosos de Uderzo, FIG. 4). La edición tradicional ha sufrido en varios álbumes de las aventuras del galo una grafía de imprenta absolutamente frígida, sin expresividad y carente de equilibrio con el resto de elementos visuales (FIG. 4 bis). Este hecho dice poco respecto al maridaje entre arte e industria del cómic en España, que es el que ciertamente sostiene, caracteriza y alimenta a la historieta. ${ }^{7}$
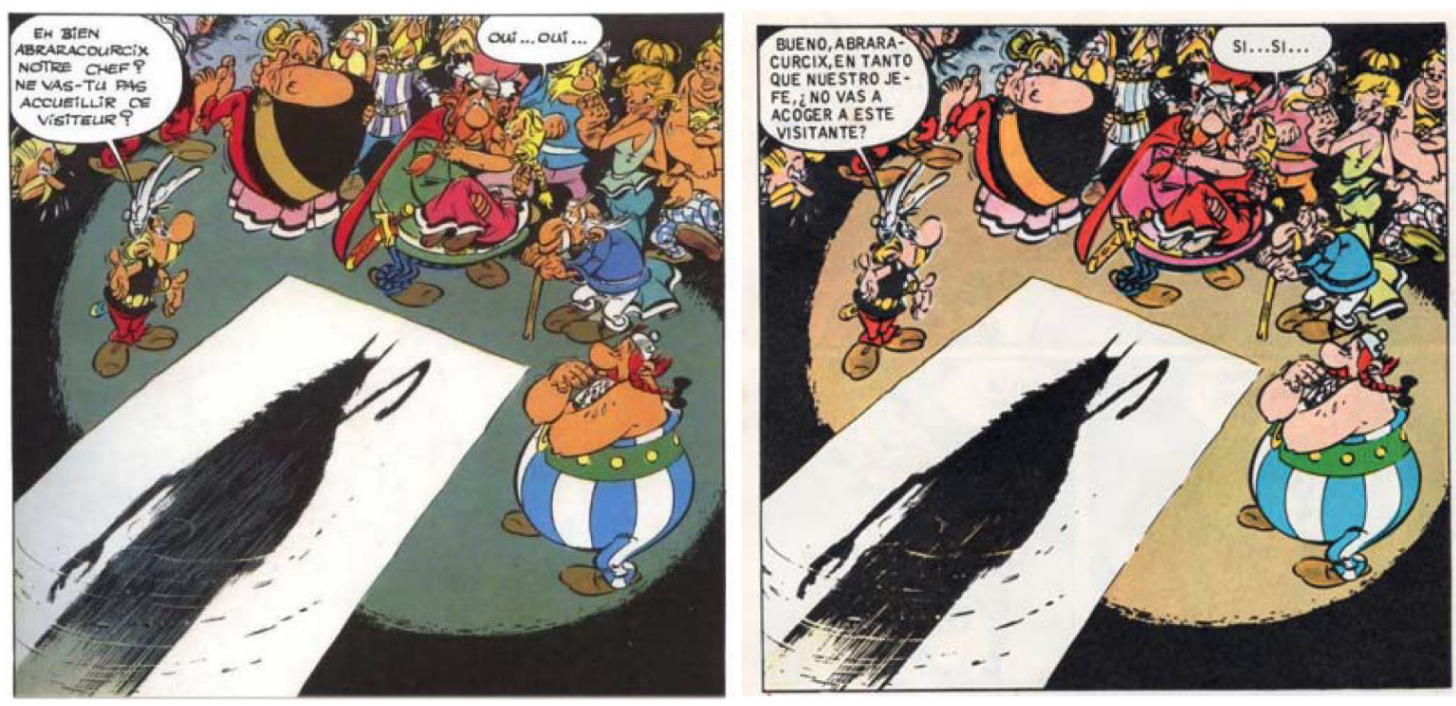

FIG. 4 y FIG. 4 bis. Astérix el Galo. El adivino, Albert Goscinny, Emile Uderzo. Hachette Livre y Salvat. 1972 y 1973 respectivamente.

\footnotetext{
7 A fines de 2011 la Editorial Salvat ha paliado esta circunstancia comenzando la edición de Astérix. La Gran Colección, donde se ha procedido a un nuevo coloreado, la recuperación de la línea de dibujo de Uderzo, y para el caso español, una nueva rotulación de todos los libros, más cercana al acabado original.
} 
Pero más allá de la dicotomía entre rotulación manual y mecánica, los avances en la informática de finales del siglo xx han permitido un tercer modo para la escritura en el cómic. Me refiero, evidentemente, a las tipografías computacionales. De hecho, hoy por hoy los autores y los rotulistas de historieta bien pueden obrar por un camino donde se unen lo tecnológico con lo manual, al proceder a digitalizar su propia escritura manuscrita, letra a letra, para trabajar con ella a modo de collage virtual, escribiendo los textos sobre la obra escaneada utilizando como tipográfía ${ }^{8}$ no una de las miles que la informática moderna pone a nuestra disposición, sino la propia del autor. De este modo es bien cierto que un lector, ante una obra contemporánea, no siempre será capaz de discernir en un primer golpe de vista si la grafía que está leyendo no dejará de ser una fuente de letra electrónica singular, única, creada ex profeso por el dibujante o el rotulista y partiendo de su propia letra manuscrita, o una rotulación manual y directa.
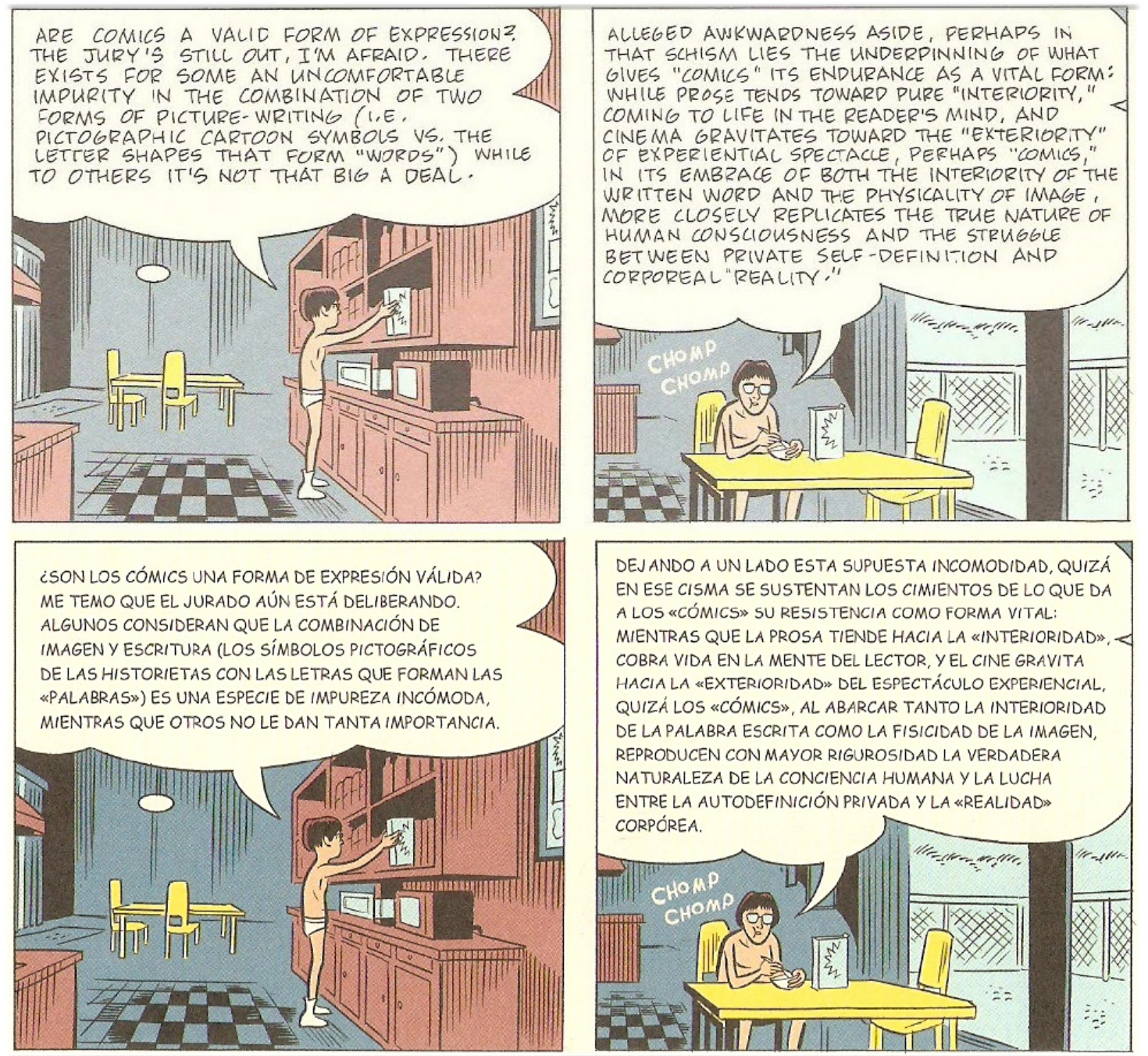

FIG. 5 y FIG. 5 bis. Ice Haven. Daniel Clowes. Fantagraphics y

Random House Mondadori. 2007 y 2008 respectivamente.

\footnotetext{
${ }^{8}$ Por tipografía, a lo largo del presente texto aplico la siguiente definición aportada por Jacqueline Murillo en "Glosario mínimo de tipografía", en el blog Nisaba. Lengua, edición, diseño y tecnologías de la palabra (consultado el 7 de dicembre de 2013): “(...) conjunto de características y decisiones que determinan el aspecto de un texto, desde el punto de vista de la forma y el diseño de las letras. Abarca el conjunto estético que compone un libro y todas las fuentes y familias involucradas en el resultado final.” MuriLlo, J. http:// blognisaba.wordpress.com/2010/08/30/glosario-minimo-de-tipografia/.
} 
En otras ocasiones la naturaleza de la fuente empleada queda más evidenciada, sobre todo en casos tan visibles como la edición de obras extranjeras, donde podrían compararse las grafías de la versión castellana y la original, y reconocer en la primera una fuente codificada. En este sentido es esclarecedor el ejemplo de las FIG 5 y 5 bis, fragmento de Ice $\mathrm{Ha}$ ven, de Daniel Clowes (1961), en la que vemos la página original, de rotulación manual (o informática personalizada), y el trasvase al castellano, que opta por la fuente "Comic Sans", bien conocida por cualquier editor de textos informáticos. Aunque el resultado evidentemente dista del gélido toque de la imprenta, pierde la viveza del original.

En todo caso, llegados a este punto y entendida la idea de que la letra puede tener diversos orígenes atendiendo a su modo de producción, la realidad es que, sea informática, mecánica o manuscrita, esta grafía se posiciona, en el marco de la página de cómics, de unos modos tan diversos como unidos al medio. Analizamos a continuación este aspecto, los diversos asientos que puede tener la letra escrita en la página de cómics.

\section{Ubicación de la letra en la página de historieta.}

Frente a otras formas narrativas donde la letra es la protagonista absoluta en tanto que único soporte visual pero no icónico (literatura) o, por el contrario, donde apenas resulta un elemento más en un espacio preeminentemente visual (como los escritos diegéticos que se pueden contemplar en el contexto de un film, o los rótulos de diálogos y narración del cine silente), en la historieta la imbricación texto-ilustración provoca una gran riqueza formal, con diversos aspectos convenientemente diferenciables. Uno de ellos es el lugar y la función que la letra escrita va a recibir dentro de la página, dependiente de dicho lugar. En este sentido, la grafía posee una función narratológica que le otorga una determinada naturaleza según dónde y cómo se ubiquen las frases escritas dentro de la página. Muchos de estos lugares ya han sido tratados con anterioridad a este estudio ${ }^{9}$ ya que el crecimiento del arte del cómic depende del afianzamiento de los diversos modos de entender la escritura dentro de la narrativa gráfica secuenciada. Y en términos generales podemos determinar cinco campos de ubicación principales: los cartuchos, los bocadillos, los textos diegéticos, las onomatopeyas y los títulos.

Los cartuchos, cartelas, cajetines o didascalias aparecen en los albores de la historia del cómic derivando de fórmulas ya bien asentadas en el humorismo gráfico satírico y en experiencias de narración icónica anteriores, y su uso permanece más o menos intacto hasta nuestros días. Si en origen su capitalidad era absoluta, consistiendo en la explicación viñeta a viñeta de lo narrado, su papel se ha ido flexibilizando. En este sentido, las cartelas, cuando son utilizadas, pueden albergar todo tipo de textos, desde acotaciones espaciales o temporales para explicar una elipsis o un cambio de escenario, hasta elaboradas secciones literarias que acompañan a la narración gráfica como en la FIG. 6, de la serie Miracleman. Aquí el escritor Alan Moore (1953) emplea los cartuchos de texto para una prosa elaborada y en primera persona, un monólogo interior del héroe. Es un texto alejado de todo naturalismo, perfectamente articulado y muy elaborado, que refleja el estado de plenitud y autoconsciencia semi-divinas que siente el héroe, combinado armónicamente con las imágenes del propio Miracleman "danzando" con las nubes: "Pendo crucificado en el cielo, como una cometa que ha perdido su guerra con el viento. Suspendido entre el barro y las estrellas, entre el cielo y la tierra, entre los ángeles y los monos. No hay nadie como

\footnotetext{
9 Ibid.
} 
yo. Soy Miracleman (el Hombre Milagro)", leemos mientras observamos al superhéroe suspendido en el cielo en pose extática. ${ }^{10}$

Por tanto, la idea de cómic literaturizado va en este ejemplo mucho más allá de la combinación rudimentaria de imagen y cajetines narrativos neutros que iluminen la escena dibujada. La expresividad de los textos escritos, cuidados con detenimiento por el guionista, se conjuga con las ilustraciones en un juego de espejos complementario. El gesto dibujado y la soberbia autoconsciente del discurso literario se mezclan, para perfilar un mensaje combinado de texto didascálico y dibujo.

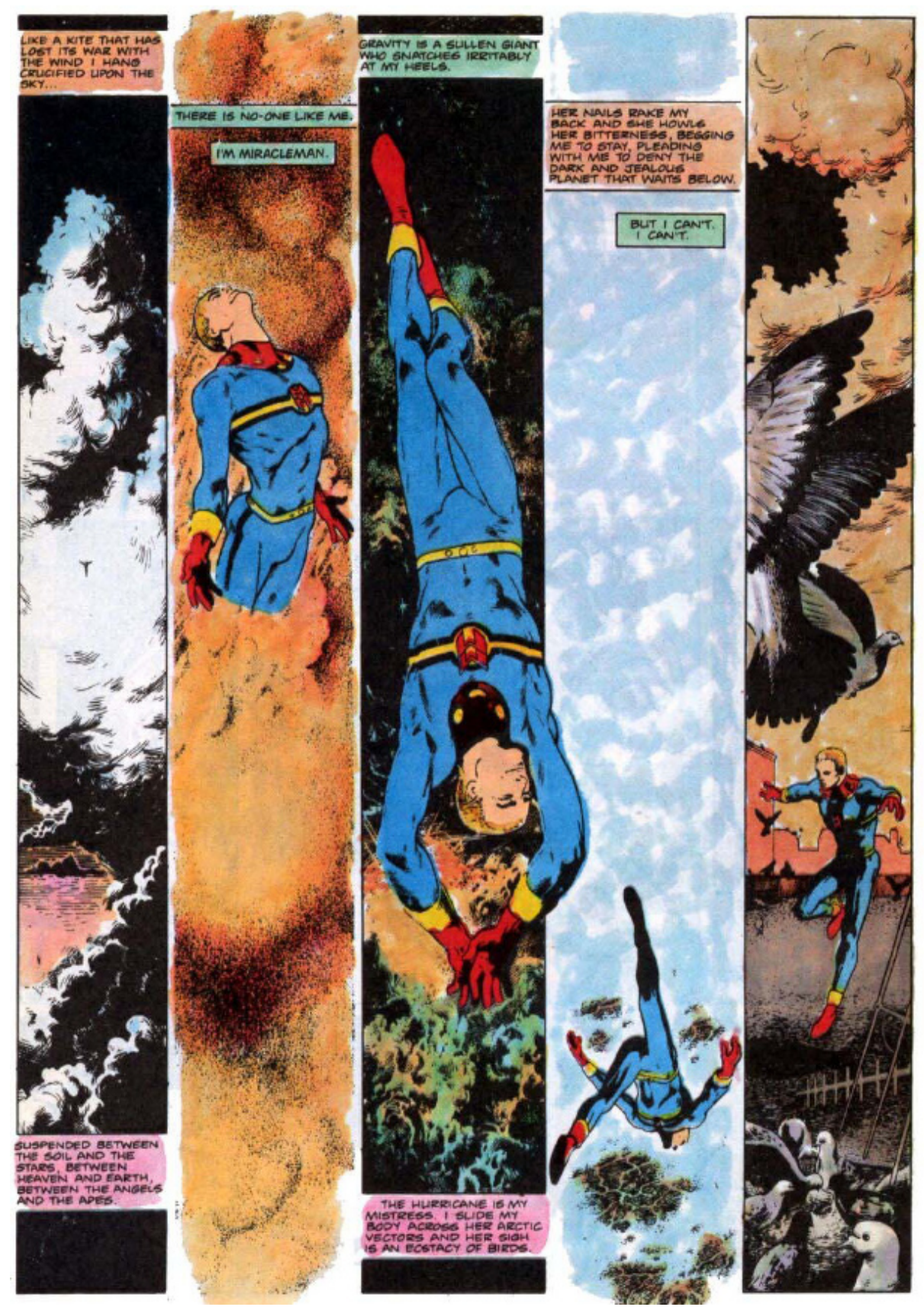

FIG. 6. Miracleman n. ${ }^{\circ}$ 2. Alan Moore y Alan Davis, 1985.

${ }^{10}$ Traducción de Lorenzo Díaz para la edición de Comics Fórum (Miracleman n. ${ }^{\circ}$ 3. Barcelona, PlanetaDe Agostini, 1990, p. 3.) 
Y la cartela puede recibir textos de un narrador omnisciente o, como plasma con claridad el ejemplo de Moore y el dibujante Alan Davis (1956), el empleo de ardides literarios como el uso de la primera persona del singular, el monólogo interior, etcétera. El cartucho es, en fin, un lugar que puede ser receptor de toda suerte de tipología textual (incluso de los diálogos), y posiblemente, por tanto, el espacio físico donde la letra escrita es, en cuanto a su naturaleza dentro de la narración, más libre.

Por contraste, posiblemente los textos escritos en globos o bocadillos supongan los elementos de escritura más férreamente acotados dentro del cómic, en lo tocante a su naturaleza narratológica. Hablamos de elementos figurativos dentro de la imagen dibujada, que lejos de representar objetos de la acción, objetos literales de la imagen narrativa, simbolizan bidimensionalmente los diálogos de los personajes y por tanto enmarcan y definen los textos que reflejan dichos diálogos. Salvo ardides exóticos, habitualmente los autores de historieta reservan dicha función, expresar los parlamentos de los personajes, tanto al elemento visual-icónico (generalmente los globos son elipses geométricas con "rabillos", expresivos del lugar del que viene el diálogo escrito) como al textual, que difícilmente será otra cosa que un texto con las frases pronunciadas por un personaje de la acción. En este sentido sí podemos comentar que, efectivamente, en ocasiones en los bocadillos se sustituye el texto de un diálogo concreto por signos icónicos o caligrafías imaginadas. Un ejemplo del primer caso se suele dar cuando expresiones de ira, agraviantes o de otro tipo son sustituidas por símbolos gráficos (tales como rayos, calaveras, o más simbólicos como un serrucho cortando un tronco para definir el sonido del ronquido). En cuanto a caligrafías inventadas, sirve de ejemplo imaginar la representación del lenguaje imaginado para una criatura extraterrestre.

Pero la realidad es que incluso en este campo restringido, globos de texto como líneas de diálogos, podemos encontrar variantes dignas de mención. Un bocadillo puede indicar un determinado sonido diegético, esto es, aquel que procede de la acción narrada. Emisiones radiofónicas, el sonido de una alarma, un teléfono, etc. El globo, en fin, contiene frases verbalizadas, pero también puede describir la naturaleza exacta de las mismas, que no siempre son directamente textos-diálogo de los personajes actantes. En la FIG. 7 aportamos un ejemplo tan sencillo como descriptivo.

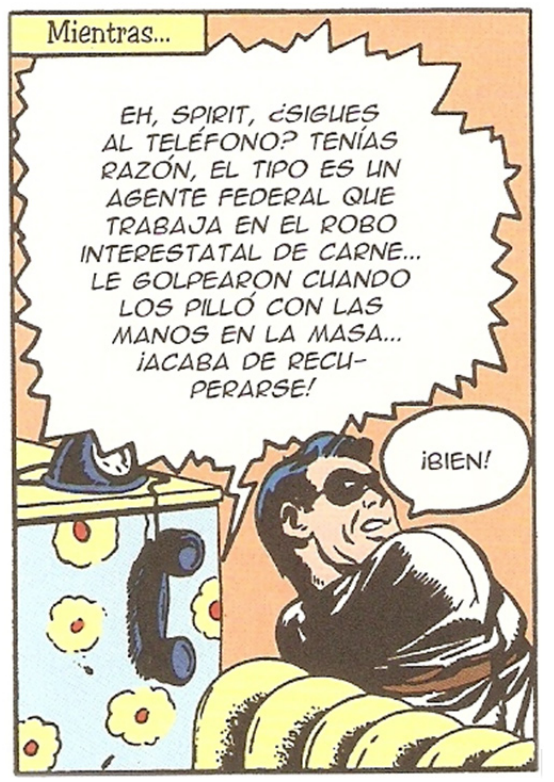

FIG. 7. The Spirit, Will Eisner, 1946. Edición de Norma Editorial, Volumen 12, 2005. 
Will Eisner (1917-2005) es el autor de The Spirit, personaje a quien observamos aquí lidiando con un teléfono. De ello nos damos cuenta no solo por el propio texto sino por su inserción dentro de un bocadillo dirigido al auricular. Al mismo tiempo, la forma de pico de sierra del globo expresa las características del sonido, presumiblemente metalizado, en una convención del bocadillo, signo icónico que se relaciona con los elementos textuales de la imagen. En definitiva, letra e imagen figurativa se entremezclan en los bocadillos de texto, para aportar un significado global.

Además el mismo recurso, variar el elemento gráfico para dar un significado preciso y nuevo a la grafía, es empleado en los cómics para expresar visualmente aquello que no es pronunciado, esto es, las líneas de pensamiento. Para ello es nuevamente el globo el que nos indica, a través de códigos icónicamente reconocibles, que el texto no es vocalizado. Hablamos de los bocadillos con forma de nube. Por lo tanto, igual que en el ejemplo de Eisner, la naturaleza de la grafía queda modificada por el elemento gráfico, por la forma del dibujo contenedor de la frase. Este hecho es capital y describe un aspecto inherente al arte de la historieta, pues en pocos más encontraremos una interrelación de elementos textuales y gráficos de la que dependa el significado final de lo que es contado con esas palabras. No al menos en el grado y la abundancia que el cómic of rece.

Hablamos a partir de la FIG. 7 de diégesis en el marco de la acción figurada, en referencia a sonidos que ocurren en la acción que se representa. En el caso, se trata de sonidos telefónicos, pudiendo en otros ejemplos ser de otra naturaleza: de los diálogos a músicas que se escuchan en la narración que relata el tebeo. Pero es necesario atender también a la importancia de los textos diegéticos, que serán aquellos documentos escritos que se pueden observar dentro de la propia ficción en un ejercicio metalépsico nada desdeñable como recurso comicográfico. Periódicos leídos por personajes, cartas de los protagonistas, vallas publicitarias, etcétera. En este sentido la letra escrita dentro de la ficción dibujada no deja de ser un componente más del dibujo. Es la ilustración de un texto que está escrito en la ficción, y que posee una iconicidad específica pues representa un cuerpo físico. $\mathrm{Y}$ al tiempo puede detallar dicha escritura, dibujar los textos diegéticos de un modo legible, haciéndonos partícipes de ella. No es baladí esto último, ya que muchas veces el ilustrador opta por insinuar la letra escrita presente en la ficción con un trazo impreciso, que evoque por su dibujo, su forma rectilínea, temblorosa, un indefinido pasaje escrito (en una postal, un diario, etcétera). Pero en otras ocasiones el dibujante detalla el texto en su dibujo, y podemos leerlo como parte de la información de la narración. Sirve como ejemplo la FIG. 8, perteneciente a Nova-2, de Luis García (1946). Esta historieta surgida durante el auge de las revistas de cómic durante la transición supuso uno de los pilares del intento, a nivel nacional, por crear un panorama de cómic adulto.

Nova-2 es una reflexión íntima y desesperanzada, ilustrada con un estilo de lápiz hiperrealista. Nos resulta interesante esta página de la obra, donde García retrata a su protagonista curioseando un quiosco callejero. Esto lo advertimos en la viñeta superior, un plano general de la escena. Y lo que está leyendo son las portadas de la prensa del día, lo que queda revelado en la viñeta inferior. García ha dibujado todas esas portadas alusivas al asesinato de John Lennon. Es puro dibujo, y es letra escrita. Lo primero, porque evidentemente estas grafías no son libres ni caligráficamente caprichosas, sino que el dibujante ha imitado el estilo de las cabeceras del diario El Caso y la revista Lecturas, así como los modos típicos de rotular que tiene la prensa en aquel momento. Y es letra escrita y no meramente insinuada, porque el ilustrador quiere que los lectores sepamos 


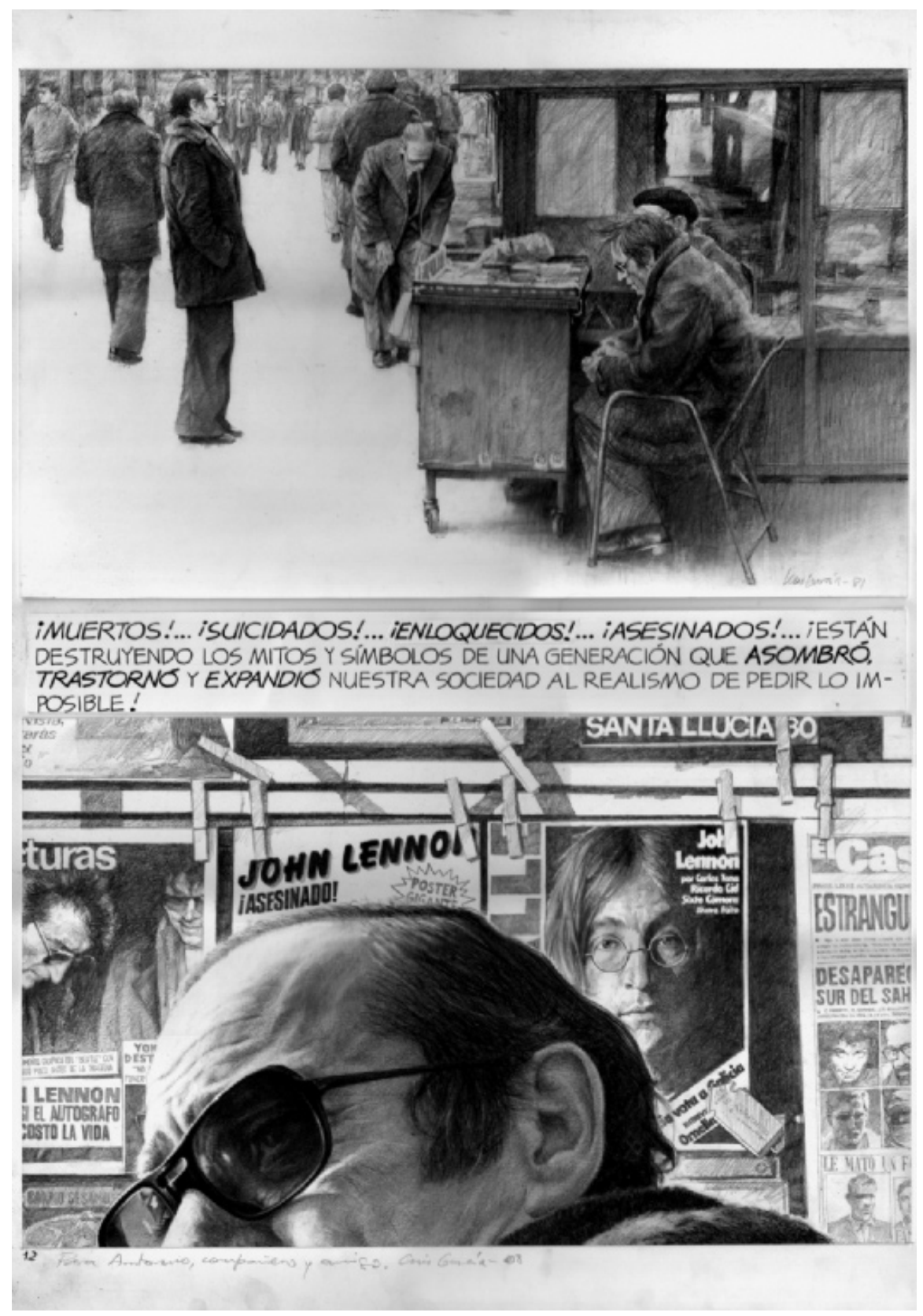

FIG. 8. Nova-2, Luis García. 1985.

qué lee su personaje, no solamente por el rostro del Beatle también dibujado, sino por los textos escritos.

Como vemos, lo normal en lo tocante a los textos diegéticos representados dentro de la ficción es que obedezcan a intenciones narrativas, ya que el ilustrador se ha esforzado en que podamos leer ese texto, precisándolo dentro de su narración. Desde un indicativo letrero en una puerta que nos advierte de qué hay tras la misma, pasando por mensajes escritos que los personajes leen (acertijos, instrucciones, misiones secretas, cartas personales...) a casos más elaborados aún, como en Nova-2. Porque en este ejemplo la escritura representada parte de un lugar secundario, el fondo, el entorno de las acciones del protagonista del cómic, para constituir un marco referencial histórico, físico y emocional. Compárese el efecto en la FIG. 9, donde la primera viñeta elude reflejar la letra en el periódico, renunciando a la figuración de lo escrito en la representación dibujada, 
mientras que la segunda viñeta, por interesar dramáticamente, sí que reproduce el texto del diario:
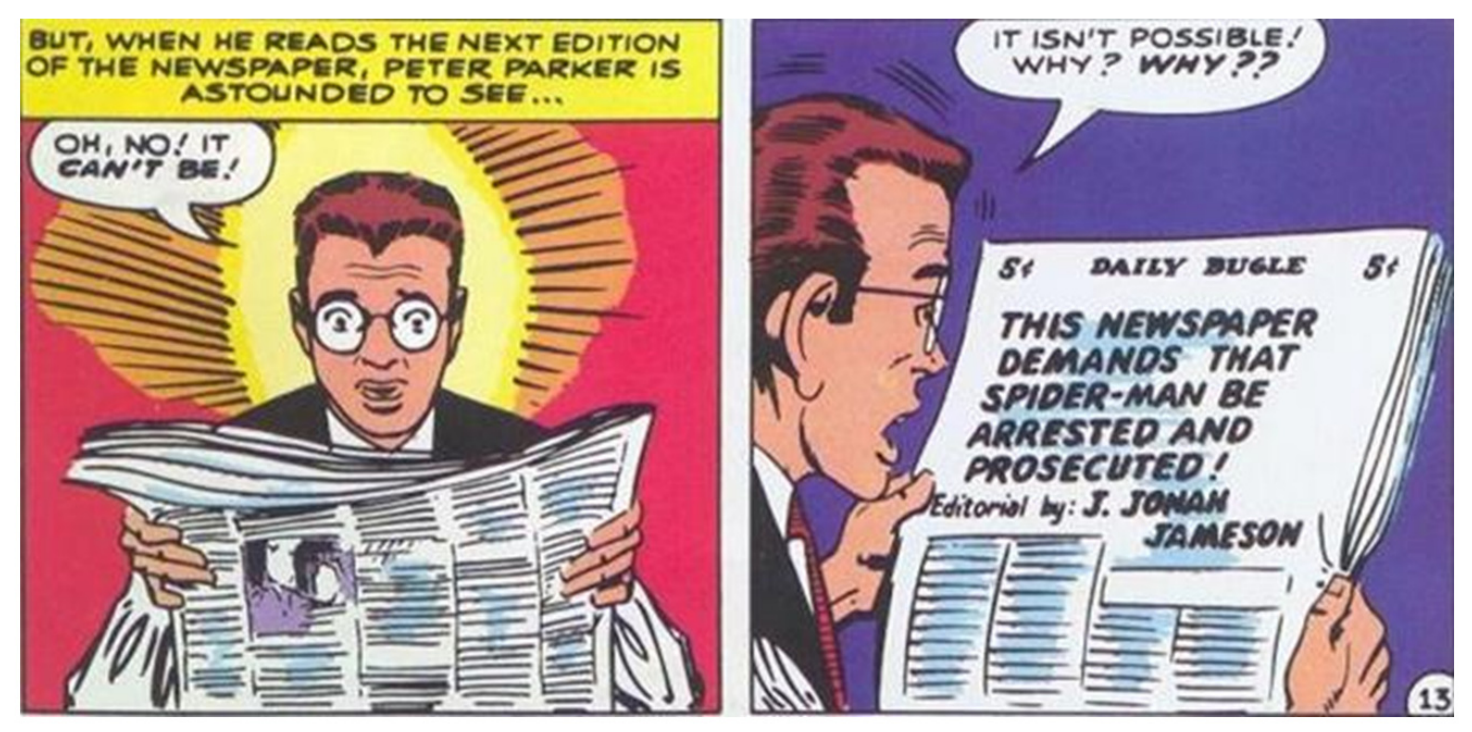

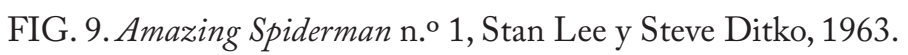

Pero si hay un lugar de auténtica simbiosis entre grafía y dibujo, entre letra e ilustración, ese es el espacio onomatopéyico. Las onomatopeyas podrían entenderse como uno de los mayores refinamientos en el viaje sintetizador de la aplicación de grafías al espacio de la narrativa gráfica. De las primeras muestras, discretos ardides léxicos para explicitar acciones como una caída, una zambullida, un golpe, etcétera, se pasará pronto a entender que esas palabras imprecisas, acaso por ser a menudo invenciones, juegos fonéticos que intentan captar sonidos naturales no verbales, tienen un mayor rango de libertad icónica que va más allá del llano texto expresivo de un mensaje. Su forma y disposición en la imagen serán tanto o más descriptivas de la naturaleza de lo que se escribe, que la unión de letras sin sentido significativo que al fin y al cabo casi siempre son esas expresiones de sonidos inarticulados. ${ }^{11}$

Por otro lado, la onomatopeya puede ubicarse dentro de globos, de cartelas, o, más habitualmente, desenmarcada de cualquier cuerpo dibujado que no sea el de las propias letras escritas. Y juega o puede jugar con formas, tamaños, trazos y colores en una mezcla inédita en otras artes, aunque acaso semejante al factor visual de la grafía en el cartelismo. Pero, dada la naturaleza de narración que poseen todos los elementos constitutivos de la historieta, en el cómic resultará mucho más rica, variada y de fines diversos. Los ejemplos son incontables, pero Walter Simonson suele ser citado como uno de los maestros en el empleo del ardid, como se ve en la FIG. 10.

Finalmente, tras contemplar la letra en función de su ubicación dentro de la página de cómic voy a atender a la escritura de los titulos de las historietas. Estos se ubican bien

11 Decimos que casi siempre porque la tradición angloparlante ha vinculado no pocas veces dichas onomatopeyas al verbo real de la acción que representa, y así para una ola que salpica fuertemente podríamos observar un "Splash!” (“iSalpicadura!”) que lo ilustraría onomaopéyicamente. No ocurre del mismo modo en la historieta española, también en tanto que nuestro idioma carece del componente altamente fonético de los sustantivos del inglés, o de alguno de ellos como el del ejemplo aquí utilizado. 

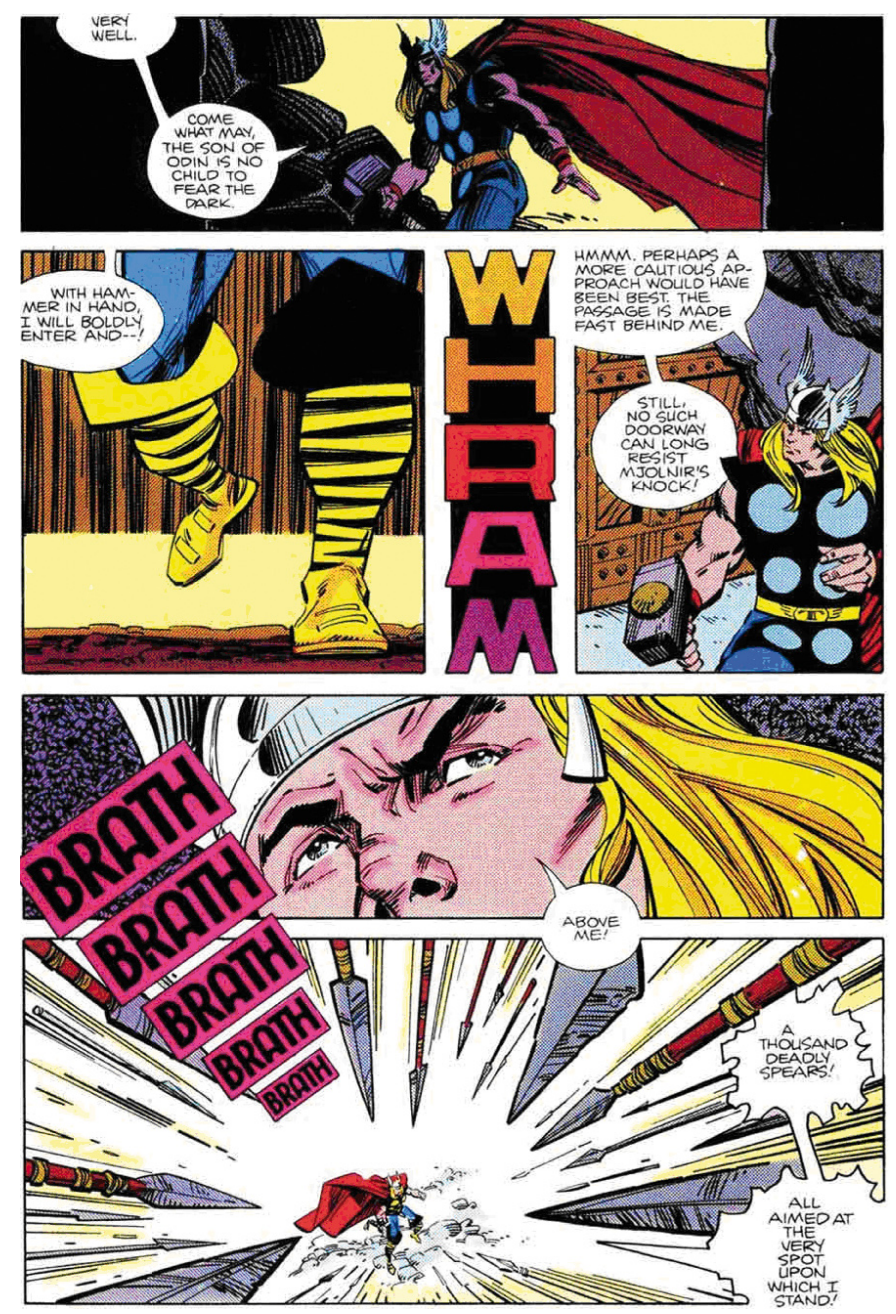

FIG. 10. Thor n. ${ }^{\circ}$ 342, Walter Simonson, 1984.

en portadas, previas por tanto a la narración historietística en sí pero parte consustancial del libro/cuadernillo de historieta entendido como un todo, bien al inicio de la propia historia encabezando la página inicial, o conformando parte de una viñeta o un grupo de viñetas del cómic en cuestión. El título posee no tanto una función narrativa como de abstracción plástica, mixturada con pura información verbal. La letra del título es puramente informativa, nos sitúa ante el nombre de la propia obra, y por ello sus características visuales son claramente pragmáticas: forma, color, tamaño, todo en el título nos hace centrar nuestra atención en él, porque es tanto la presentación primera de la obra (en tanto que información textual) como, por dichas forma y apariencia, un reclamo comercial. Fija en nuestra memoria visualmente la obra por su "nombre propio", al que asociaremos una imagen icónica, la del texto que lo representa.

Una vez más, estamos ante letra-dibujo en muchos casos y en grados variables, pues el título supone un identificador claro. Más aún si hablamos de series fijas de personajesicono. Si pensamos en los primeros años del comic-book The Amazing Spiderman, de Stan Lee y Steve Ditko (Marvel Comics, 1962) o en series de la Edad de Oro como Principe Valiente (1937) de Harold Foster o Terry y los Piratas (1934) de Milton Caniff, la grafía empleada en el título, habitualmente correspondido con el nombre propio del héroe protagonista, permanece invariable en sus mínimos detalles durante años, lo cual supone un gancho visual. El lector del diario o el individuo que curioseaba ante el quios- 
co, como el ficticio personaje de Luis García que hemos conocido en Nova-2, no solo reconocerá visualmente su tebeo favorito en un golpe de vista sino que, más aún, la forma familiar de su título llamará casi subliminalmente su atención, de un modo previo al ejercicio intelectual que supone la lectura significativa de aquello que tiene ante los ojos.

El título tiene ese cariz comercial, hace primar la fuerza del "golpe visual" de una rotulación muy gráfica y de fuerte impronta icónica, que busca formas, volúmenes y cromatismos para llamar la atención de un modo previo al acto de leer. Sin embargo el talento diseñador de los dibujantes de cómic ha sabido llevar más allá esta idea comercial. Aunque está claro que la función de un buen título será lograr el reclamo visual, no es menos obvio que siempre la estética jugará un papel importante en el diseño de un título. La FIG. 11 es paradigmática y nos ayuda a entender cómo el título de una historieta puede alcanzar expresividad en el marco de la narración que viene a bautizar. Se trata de la viñeta de apertura de Atom Bomb, de Harvey Kurtzman (1924-1993) y las ilustraciones de Wally Wood (1927-1981) publicada en 1953 en Two-Fisted Tales número 33, revista de temática bélica de la editorial EC Comics. Curiosamente, aunque el magacín incluye cuatro historietas y todas ellas se titulan con un mismo grafismo, en el caso apuntado es especialmente logrado el efecto expresivo, emocional y de verdadera narración por medio de imágenes, entendidas las letras como dibujos.

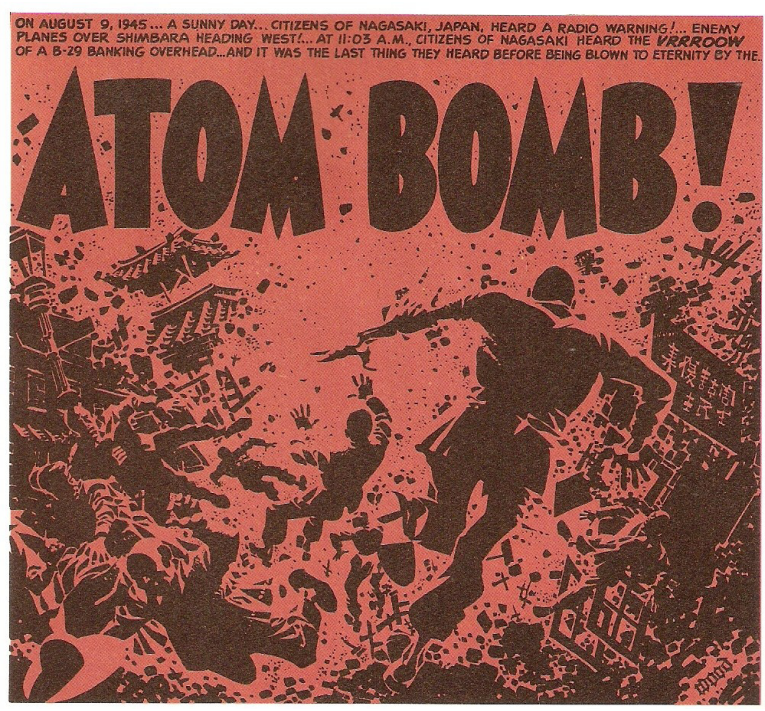

FIG. 11. Atom Bomb. Harvey Kurtzman, 1953.

“BOMBA ATÓMICA!”, reza su título en llamativas mayúsculas, y evidentemente tanto su enorme tamaño, "cinemascópico" en tanto que abarca toda la longitud del extremo superior que lo aloja, como el propio dibujo de la grafía, buscan el efecto impactante, explosivo, que atribuimos a toda gran detonación: combinando líneas levemente curvas y expansivas con ángulos muy marcados, cortantes, ubica al lector, en perfecta simetría con los restantes elementos de la viñeta, en un contexto de innegable peligro. Esto otorga a la obra, de antemano, un determinado vigor acentuado por el color negro sobre fondo monocromo. El propio título, por tanto, nos introduce en la narración antes de comenzar la historia, genera un marco de lugar y circunstancia, propone al lector el tono de la narración que se dispone a leer. Nadie, evidentemente, se imagina por este título que lo que bautiza pueda resultar una fábula contemplativa o plácida, sino vertiginosa y abocada a la acción y el peligro. 
Y por esta vía, sofisticando la grafía del título y su función, podemos acudir a ejemplos más elaborados todavía, como, nuevamente, el conocido caso del cómic The Spirit de Will Eisner. Obra avanzada e innovadora, consistía en una publicación de siete páginas formando relatos autoconclusivos. El título se vendió entre 1940 y 1952 con los diarios, inserto en su suplemento dominical, que aglutinaba varias historietas. Y cada nueva aventura semanal repetía el título, "The Spirit". Eisner, frente al modo habitual ya referido (la repetición sistemática para la rápida identificación de su obra) optó por jugar con su título variando continuamente su forma, dibujándolo de los modos más imaginativos dentro de la primera página de su cuaderno. Las letras del nombre del héroe aparecen así cada semana ilustradas de las maneras más inimaginables y mutantes: como bloques de hormigón, como papeles mojados discurriendo hacia un desaguadero, adoptando la forma de edificios en imposible picado o carteles encolados en un muro, etc. La FIG. 12 es un ejemplo de esta originalidad, capaz de convertir algo posiblemente rutinario como no olvidarse de incluir en cada nueva entrega el título, en una experiencia estética y narrativa. Analicemos el ejemplo: "The Spirit”, El Espíritu, es el héroe enmascarado protagonista de la ficción, ${ }^{12}$ y resulta sorprendente como Eisner utiliza la grafía del título para crear algo completamente inserto en la narración.

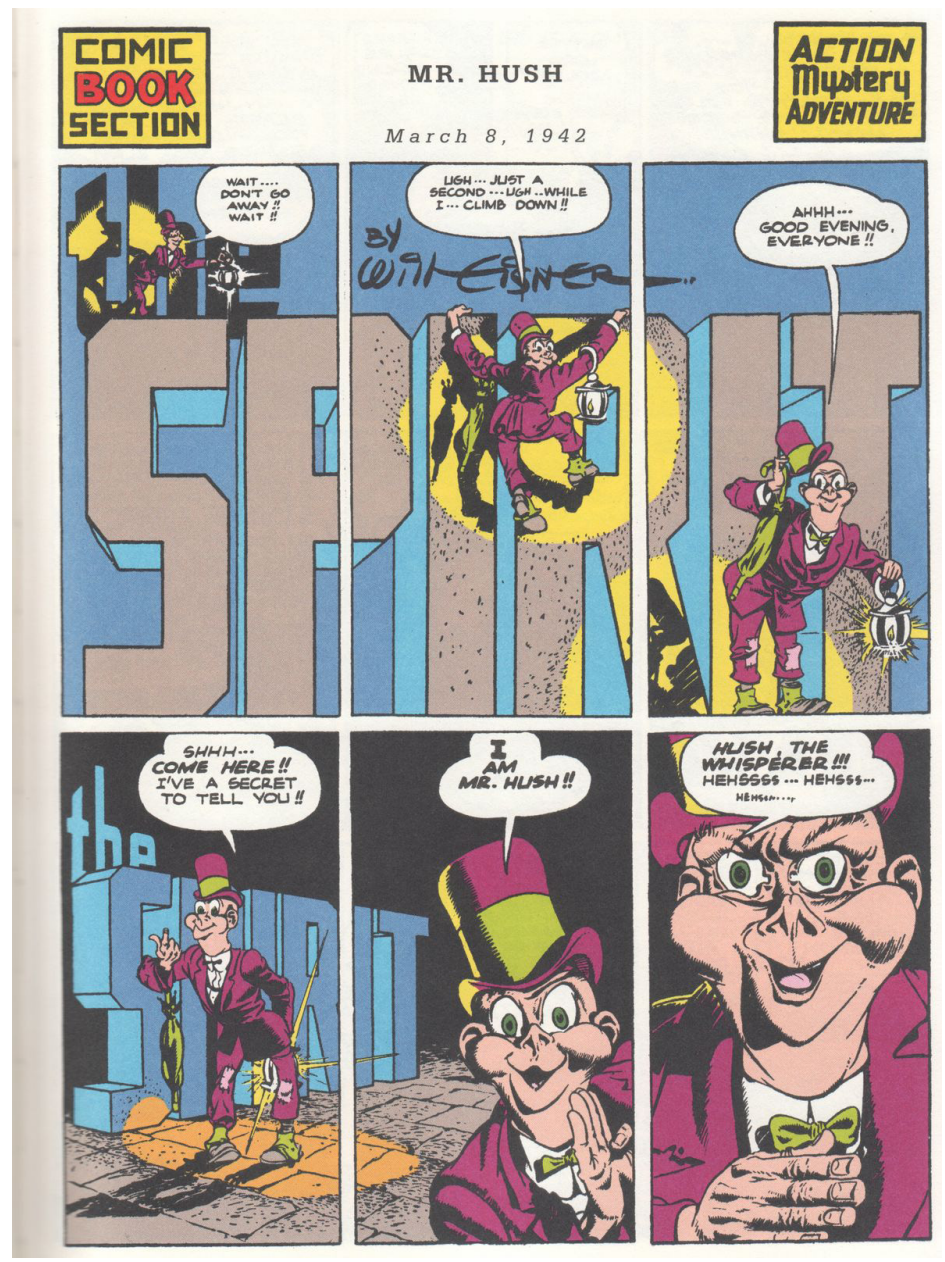

FIG. 12. The Spirit, Will Eisner, 1942.

\footnotetext{
${ }^{12}$ The Spirit se trata de un justiciero por una cuestión pragmática. Nace en la época de esplendor de los superhéroes, pero hay que reconocer que poco se parece en tono e intenciones a los héroes en esquijama. Se trata más bien de una serie híbrida, donde confluyen el cine de gánsteres de su tiempo, las aventuras urbanas, el humor, lo social y cierto gusto folletinesco.
} 
Nos enfrentamos aquí a una lexía. Rubén Varillas define las lexías explicando que se producen "Cuando las herramientas del lenguaje comicográfico trascienden sus funciones instrumentales habituales para cargarse de connotaciones activas dentro de la historieta". ${ }^{13}$ Se produce por tanto cuando un globo, una cartela o, centrados en el registro que atendemos en estas líneas, un título, adquiere connotaciones físicas dentro de la historia, con un rol activo dentro de la propia narración. Verdadero metalenguaje que permite que la grafía se convierta en elemento plástico y real, en cierto modo, dentro de la narración que se está desarrollando.

Analizando el ejemplo propuesto, en la primera viñeta el artículo "The" es presentado como un vano, una suerte de agujero en el fondo neutro de la escena mientras que el nombre propio, "Spirit", "Espíritu", recibe el tratamiento de sólidos bloques tridimensionales, pétreos incluso (no se nos escapa qué se supone que es un espíritu, un fantasma, una figura etérea e incorpórea; apréciese el contraste entre el significado y la forma del significante). Y además, el título se fracciona entre las tres viñetas superiores y participa de la acción: un personaje "entra" en escena a través del agujero "The", se descuelga apoyándose en la letra "I" y la "R" y finalmente, delante de la segunda "I", se acerca "a cámara" y nos saluda a los lectores. Por tanto el título es parte protagonista del travelín que propone esta tira de tres viñetas superiores.

Pero no termina aquí el juego que nos ha propuesto Will Eisner: el individuo continúa su diálogo con el lector rompiendo la cuarta pared mediante una metalepsis por la fila inferior, acercándose a cámara viñeta a viñeta. El punto de vista se ha alejado de la escena y vemos ahora el título en segundo plano y en escorzo, lo que incide en la idea inicial: este título es tratado como un cuerpo físico, por lo que podemos contemplarlo desde distintos puntos de vista, sea el frontal de las tres viñetas superiores, sea el lateral como en las tres inferiores.

Podríamos ofrecer muchos más ejemplos, autores que tomando buena nota de las imaginativas ideas de Eisner han realizado verdaderos equilibrios formales con los títulos de sus obras, así como con sus cartelas y bocadillos, y por supuesto con sus onomatopeyas, jugando entre lo gráfico y lo textual. Algunos los veremos sin duda en el capítulo 3, al tiempo que atendemos a nuevos aspectos referentes a la letra en la historieta.

\section{La letra como elemento estético y visual.}

La letra en la historieta, lo estamos viendo, ofrece un vasto campo de estudio, muchas formas de aproximarse a ella. Pero más allá de su función descriptiva, expresiva e incluso de elemento narrativo (aspecto en que me detendré en un futuro estudio), los autores de cómic entienden la grafía como forma, y por tanto como estética, belleza visual y deleite para la mirada. Ya que un tebeo es ante todo imagen dibujada, la escritura puede ser también ornamental. En este sentido recupero ahora todo lo escrito sobre la letra de imprenta al inicio de este texto, y lo hago para desdecirme. O para matizar, cuanto menos, la idea de que dicho proceso mecánico carezca de matices estéticos, como he apuntado en el capítulo primero. Ya entonces advertía efectivamente que en ocasiones (más contadas que abundantes, bien es cierto) el empleo de letra mecánica obedece a una elección consciente del propio autor por su vertiente estética. Paradigma de ello es el clásico Barnaby, de Crockett Johnson (196-1975), que podemos ver en la FIG. 13.

${ }_{13}$ Varillas, R. La arquitectura de las viñetas. Sevilla. Viaje a Bizancio Ediciones, 2009, p. 93. 

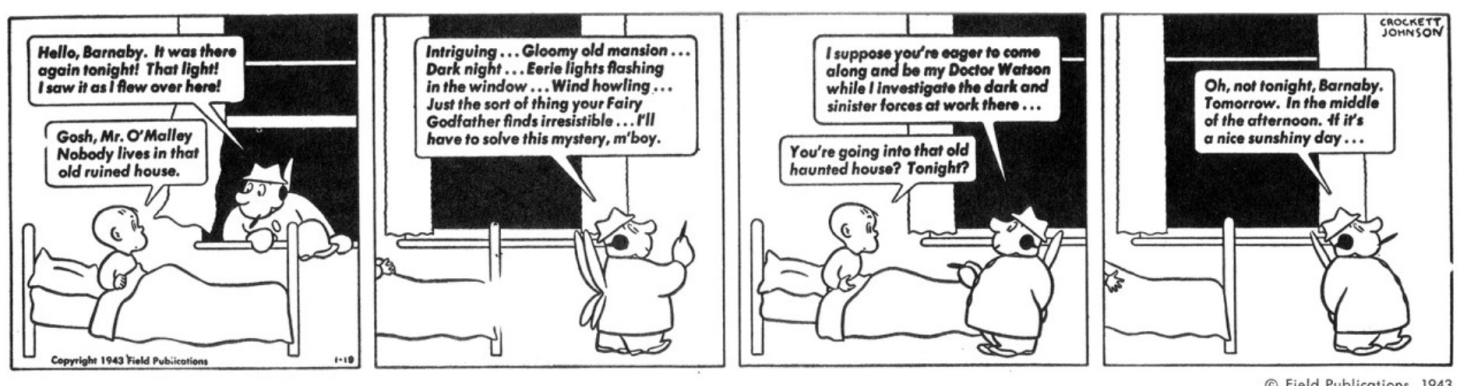

FIG. 13. Barnaby. Crockett Johnson , 1943.

En esta tira de prensa cómica sobre las andanzas de un niño y un duende fumador de puros el dibujo es regular y frío, evita la expresividad del pincel y de su trazo fluctuante. En consonancia con este estilo limpio y racional el propio autor elige que sus textos sean escritos con la aséptica letra de imprenta. ¿Podemos encontrar valores narrativos en esta opción? No es descartable, evidentemente, pero sobre todo queda patente una opción visual, ornamental.

No es un caso demasiado común, sino más bien excepcional, el de aplicar letra de imprenta con un concepto estético o narrativo, pero hay más ejemplos. John Jay Muth (1960) en su recreación de la película de Fritz Lang $M$ el vampiro de Düsseldorf, une esta tipografía de imprenta a un dibujo realista, fotográfico y cercano al estilo de Luis García en Nova-2, si bien más atmosférico, ligeramente impresionista, con lo que se genera un contraste entre el dibujo y la letra escrita.

Sin embargo donde mejor veremos esa capacidad puramente decorativa de la letra de un autor es en las grafías de creadores preocupados por el efecto plástico, incluso pictórico, de aquello que escriben en sus páginas. Hay numerosos autores que podrían citarse, por supuesto: Alberto Breccia en sus últimos años abrazó el empleo del color en su obra, un color pictórico que evoca los movimientos vanguardistas figurativos del siglo xx, sobre todo el expresionismo y el fauvismo, y que en tal contexto dotó de enorme importancia a la caligrafía. La FIG. 14 pertenece a su relato breve Dibujar o no. Y otro buen ejemplo lo tenemos en la FIG. 15, del valenciano Miguel Calatayud (1942) y perteneciente a su cómic Conquistadores en Yucatán. La desaparición de Gonzalo Guerrero.

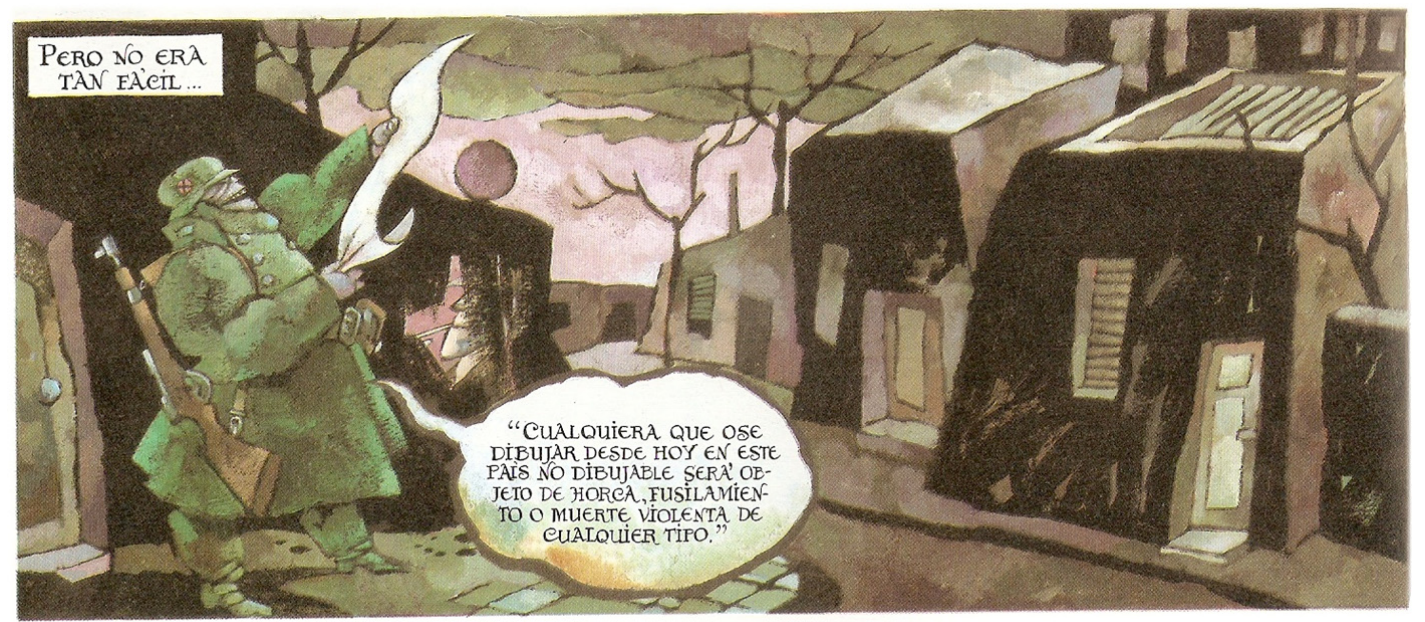

FIG. 14. Dibujar o no. Juan Sasturain y Alberto Breccia, 1986. 


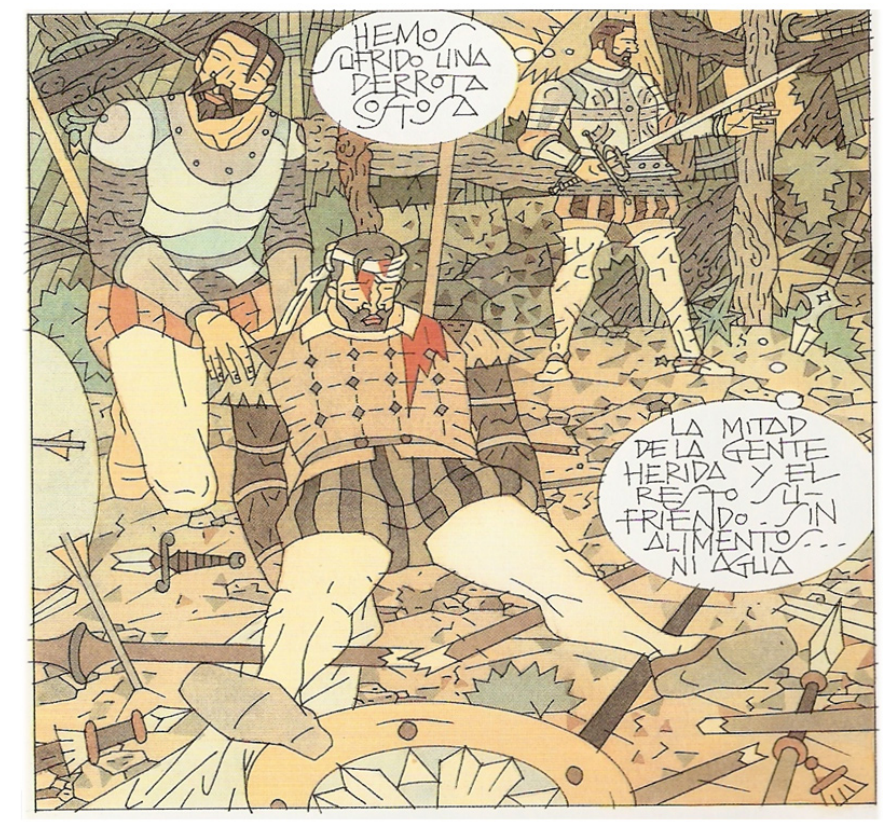

FIG. 15. Conquistadores en Yucatán. La desaparición de Gonzalo Guerrero. Miguel Calatayud, 1992.

Poco cabe añadir a este respecto. Ambos ejemplos son clarísimos modelos que evidencian la necesaria compenetración estética de la letra y el estilo gráfico del autor, y es una idea que podremos rastrear en ejemplos desde los tempranos tiempos de Krazy Kat. Los autores buscan una caligrafía que comulgue con la impronta gráfica de sus ilustraciones, aplicándola continua e invariable para toda una obra. Es un signo de cuidado visual, que empapa al elemento escrito de sus historietas, y como tal actúa de un modo indivisible con el dibujo. No siempre el resultado es tan evidente como los ejemplos aquí mostrados pues la impronta pictórica de ambos autores, cada cual desde ópticas casi opuestas, hacen de su caligrafía un elemento fundamental y ciertamente llamativo en el todo que es la página. Pero incluso en obras donde la grafía se nos aparece, en principio, menos sofisticada, el cuidado autoral por la esencia gráfica de su obra afecta también a la letra empleada. Podemos citar a Dave McKean, Max, Moebius, Manel Fontdevila o a tantos otros: en cada uno de ellos podremos aproximarnos a sus obras y contemplar como la letra elegida armoniza con los aspectos más icónicos, el dibujo, el color y las formas de los diversos elementos empleados, las viñetas, cartelas, bocadillos etcétera. La letra es el vehículo para aprehender un mensaje, pues con ella, evidentemente, se nos están narrando unos acontecimientos, una idea. Pero de la forma, el dibujo de esa letra, se obtiene un objeto bello y armónico en la página de historieta.

Y por último, si entendemos que la letra escrita es forma y diseño, dibujo incluso, podemos advertir que determinadas épocas, tendencias, escuelas o incluso estilos pueden identificarse por un determinado modo de plasmar esos textos. No hablamos ahora de adoptar una grafía acorde a un tono, o a un género literario donde adoptará una función narrativa por su forma, sino que me refiero a como una determinada estética general o coyuntural influye en la elección de la caligrafía de un autor o de una generación de autores apegados a esa corriente cultural.

Posiblemente el caso más claro sea el de los últimos años sesenta y primeros setenta. La época de la psicodelia, la estética hippie, el pop-art y las aventuras lisérgicas con el LSD ha marcado al arte, desde la pintura hasta el cine o el cartelismo. También a la publicidad, y a 
la moda. Marcó, en fin, una sensibilidad occidental que tiene claro eco en la historieta. La FIG. 16 corresponde a Ulysse, de Jaques Lob (1932-1990) y Georges Pichard. En su libérrima versión de La Odisea Pichard desarrolla todo su imaginario psicodélico, una suerte de universo de formas orgánicas y voluptuosas.

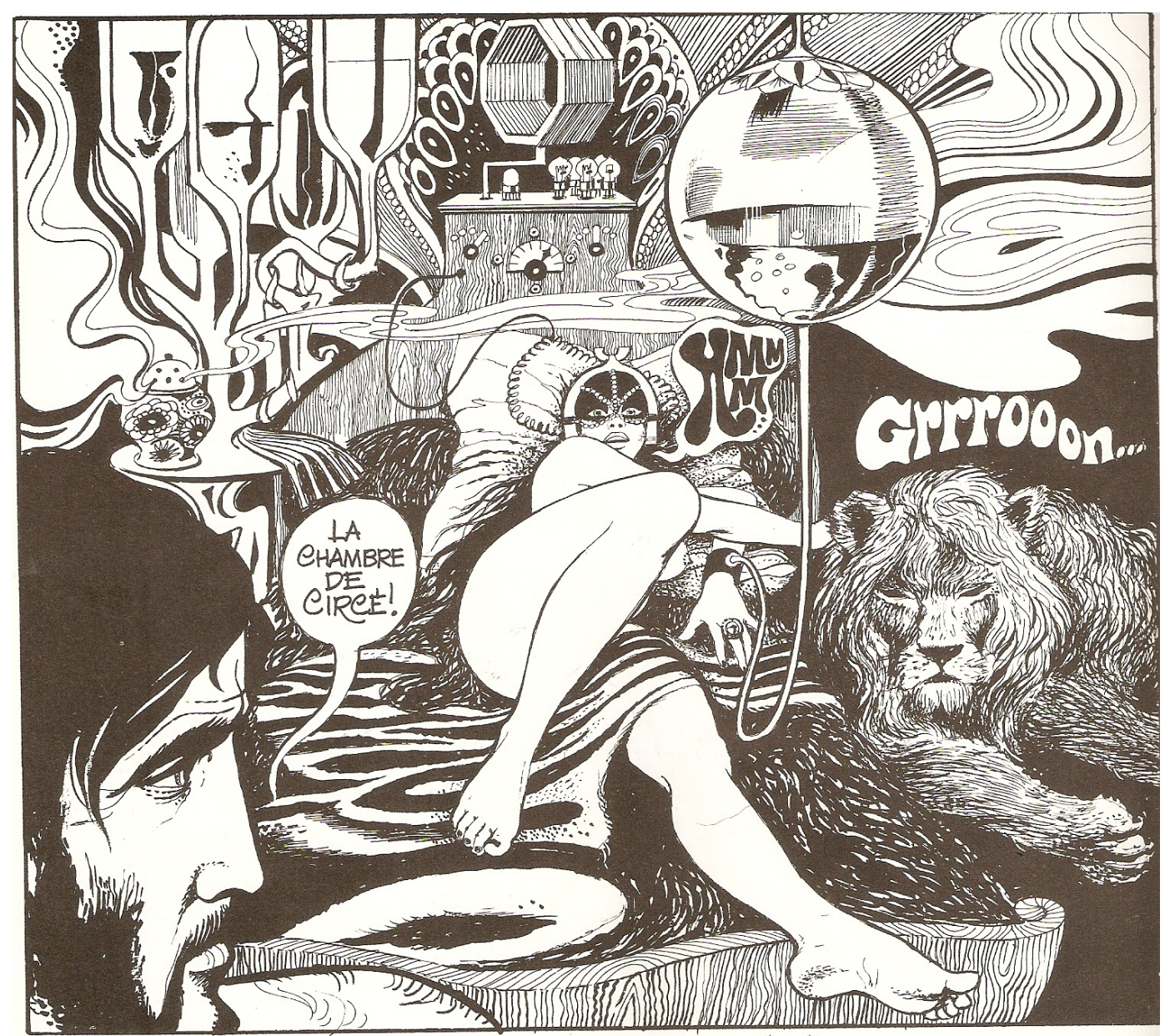

FIG. 16. Ulysse Lob y Pichard, 1974.

La letra busca en las líneas de diálogo un refinamiento paralelo, e incluso se convierte en parte consustancial de esas ilustraciones de trazos curvilíneos, formas fluidas que evocan elementos de la naturaleza. Tanto el murmullo de la fémina como el arrullo del león se ensamblan, en este sentido, con los elementos de la escena: el estampado de la manta, las formas femeninas, los alambiques, los gases que manan del incensario, las extrañas máquinas... la letra es aquí una parte más del dibujo y nos evoca sin lugar a dudas una estética determinada, acotada en el tiempo, entre los últimos años de la década de los sesenta y los primeros setenta.

No es el único ejemplo al que podríamos acudir: la grafía de Guy Pellaert, la herencia del poso artie de estos movimientos sociales en la revista francesa Metal Hurlant, la agresividad mórbida de numerosos "comix" underground, ${ }^{14}$ pertenecen a un tiempo y reflejan ese momento estético, tanto en las cuestiones gráficas como en las caligráficas.

${ }^{14}$ Los últimos sesenta son el tiempo de un cómic contracultural en Estados Unidos, autoeditado y con-
testatario, que se ha llamado "comix", para diferenciarse de la vertiente más comercial de la historieta 
Podríamos indagar en más casos, pero básicamente aportaríamos ejemplos y variedad para incidir en el mismo concepto: las escuelas (pensemos en la línea clara inspirada por las obras de Hergé), los movimientos (el citado underground), las épocas, también se han definido por el modo en que han cuidado la grafía en la historieta como parte estética de la obra.

\section{Conclusión.}

Sin entrar en valorar la manida sentencia que entiende a la historieta como narración donde se utilizan dibujos y escritura, durante el desarrollo de este estudio hemos comprobado como esta cuestión va mucho más allá de suponer un frágil signo identitario. En los diversos apartados desarrollados he descrito la capacidad de mutar, adaptarse, definir narrativamente, evolucionar con el signo de los tiempos o poseer diferentes significados según su lugar, forma, disposición y hasta dependiendo de su naturaleza manual o mecánica.

Elemento primordial de narrativa pero también de estética, la simbiosis que ha logrado la letra con el dibujo secuencial (base del cómic como lenguaje), ha servido para, además de consolidar el carácter de modo artístico único de la historieta, conseguir en sí misma y como grafía una naturaleza y riqueza de significados, por su empleo en la página de cómic, que nunca había logrado en medios menos icónicos o escasamente narrativos. E1 punto medio entre imagen dibujada y narración que es la historieta se ha revelado marco ideal para enriquecer las propiedades de la letra.

norteamericana. Son tebeos como Los Fabulous Freak Brothers de Gilbert Shelton (1940), la revista Zap! de Robert Crumb o las obras de Vaughn Bodé (1941-1975). 